\title{
The New "Podagogy": Incorporating Podcasting into Journalism Education
}

\author{
Michael Huntsberger \\ Linfield College
}

Alan G. Stavitsky

University of Oregon

Follow this and additional works at: https://digitalcommons.linfield.edu/mscmfac_pubs

Part of the Communication Technology and New Media Commons

\section{DigitalCommons@Linfield Citation}

Huntsberger, Michael and Stavitsky, Alan G., "The New "Podagogy": Incorporating Podcasting into Journalism Education" (2007). Faculty Publications. Published Version. Submission 7.

https://digitalcommons.linfield.edu/mscmfac_pubs/7

This Published Version is protected by copyright and/or related rights. It is brought to you for free via open access, courtesy of DigitalCommons@Linfield, with permission from the rights-holder(s). Your use of this Published Version must comply with the Terms of Use for material posted in DigitalCommons@Linfield, or with other stated terms (such as a Creative Commons license) indicated in the record and/or on the work itself. For more information, or if you have questions about permitted uses, please contact digitalcommons@linfield.edu. 


\title{
The New "Podagogy": Incorporating Podcasting into Journalism Education
}

\author{
MICHAEL HUNTSBERGER AND ALAN STAVITSKY
}

This report documents the results of a pilot study of the use of podcasting technology in a lower division course at the University of Oregon School of Journalism and Communication. Based on a survey of 209 undergraduate students, the study reports high levels of usage and satisfaction with content and delivery, and suggests the technology added value to class content for students.

The sight of students sporting tiny white "ear bud" headphones has become commonplace on campus. Those ear buds are almost certainly connected to Apple iPods or other personal audio devices. The devices allow students to tune out the world and tune in to music, audio books, or a more recent phenomenon-podcasts.

Just as broadcasting became the generic term for distributing content over the electromagnetic spectrum, podcasting describes the distribution of discrete audio (and now video) programs over the Internet. As the expression has caught on with the press and the public, the technology has pene- trated American culture: Bridge Ratings LLC estimates that nearly five million people downloaded podcasts in 2005 , up more than $500 \%$ from 2004. Bridge projects that 63 million people will be plugging into podcasts by $2010 .{ }^{1}$ Many users are young people: A survey by the National Retail Federation found that more than $55 \%$ of students between the ages of 18 and 24 planned to purchase electronic devices, including iPods and other portable audio players, at the start of the 2005-2006 academic year. ${ }^{2}$

It's no surprise, then, that educators are experimenting with podcasting to deliver lectures and other content to

Michael Huntsberger (MHUNTSBE@UOREGON.EDU) is a Ph.D. candidate and Alan Stavitsky (AGS@UOREGON.EDU) is associate dean, School of Journalism and Communication, University of Oregon. 
students. Apple's iTunes Store lists more than 700 programs in the education area of its podcast directory, many from U.S. universities. ${ }^{3}$ Drexel University offers a series of one-minute podcasts to help students succeed in its online courses and degree programs, ${ }^{4}$ while Stanford has partnered with Apple to offer podcasts of lectures and interviews with visiting scholars and dignitaries. ${ }^{5}$ But some observers worry that the convenience of podcasting will lead students to stop taking notes, or skip classes altogether. ${ }^{6}$

In fall 2005, Alan Stavitsky, University of Oregon, was looking for ways to use podcasting to supplement, rather than replace, the classroom experience. The result was a pilot project in the introductory mass media and society course, culminating in a student survey to understand how they used the podcasts, and to assess the experiment. This article describes the project, presents survey data, and suggests ways that the information may be useful to educators who are interested in this growing technology.

\section{Recent Electronic Experimentation}

For nearly a century, educators have been experimenting with curriculum delivery using a variety of electronic technologies, from radio, to closed circuit television, to the Internet. Pavlik asserted that digital communications technology could extend teaching and learning "across traditional boundaries of time and space. The classroom need not be the end of the discourse. Instead, through the Internet and other emerging technologies, students and teachers can engage in con- tinuing, often asynchronous discussions of the topics salient to the day and subject."7

Such possibilities spurred educators to undertake a variety of projects. The University of Oregon's ambitious distance learning project of 1995 involved 580 students at four institutions in three classes, delivered by twoway video and audio satellite connections to remote locations statewide. ${ }^{8}$ Though Reis, Stavitsky, Gleason, and Ryan considered the project to be "reasonably successful," students criticized the lack of direct interaction between students and faculty across hundreds of miles, while faculty experienced a significant increase in workload. ${ }^{9}$ In a more focused effort at Middle Tennessee State, Blake developed and implemented a computer-mediated news-writing course for classes of fifteen to seventeen students. Survey respondents found the course to be "highly enjoyable, convenient, interesting, and useful," while student work showed indications of improvement. ${ }^{10}$ Similarly, Henderson used a Webbased Targeted Approach to Grammar System (TAGS) to provide immediate responses to grammar problems in student writing. After fourteen weeks of testing to eliminate the application's targeting errors, the system effectively reduced grammar problems in the University of Colorado's student newspaper. ${ }^{11}$ These Web-based tools and techniques demonstrate that online applications and delivery can contribute to positive outcomes for students.

While it has been possible to transfer audio files across the Internet for more than a decade, the technology became prominent with the emergence of intuitive, Web-based graphical user 
interfaces, and the broader availability of publicly accessible high-speed networks. Developed initially by former MTV personality Adam Curry and public radio producer Christopher Lydon, ${ }^{12}$ among others, podcasting came to public prominence in June 2005 with the release of Apple's iTunes 4.9 software-which added a podcast directory to the already popular music downloading service. ${ }^{13}$ The following August, Princeton offered audio podcasts of public speeches from a variety of campuses, including Harvard, Rutgers, and the universities of Chicago, Michigan, and Pennsylvania through its University Channel Web service. ${ }^{14}$ In October 2005, The Chronicle of Higher Education reported on podcasting initiatives at Purdue and American University. ${ }^{15}$ A similar story in the New York Times reported the possibility that "every word of every lecture in a semester could be made available to any student with an MP3 player (not just an iPod). Students could replay the lecture anytime, anywhere." 16 On a more ambitious scale, Apple is currently seeking partnerships with institutions to develop course podcasts and other materials that will be available exclusively to enrolled students and faculty. ${ }^{17}$ Stanford's initiative, Stanford on iTunes, went live in November $2005 .^{18} \mathrm{Up}$ to this point, none of these efforts to connect the curriculum and podcasting have been considered in scholarly literature.

Podcast lectures have been criticized as an attractive substitute to class attendance, and some assert that students will skip classes if they have a more convenient method to access course materials. Read found that "most professors who podcast admit that they take special steps to keep stu- dents from simply tuning in to class on their iPods."19 Concurrently, podcasting professors express concern about their ability to sustain student interest. Such apprehensions were bluntly articulated by Purdue chemistry professor G. Marc Loudon: "I don't think most professors, no matter how good they are in class, can avoid being boring as hell when they're recorded." 20 Students, on the other hand, may take a more expansive view of the technology, viewing it "as an accompaniment to course web pages and other online study tools."21

Based on the literature, this project sought to develop and assess a way to integrate podcasting into course materials in a manner that would enhance, rather than replace, classroom lectures and discussions. In an introductory mass media course, faculty and staff brought basic audio production and online presentations skills to specific elements of the course material, and made this material available to enrolled students through the class Web site. While audio materials were not made available on a subscription basis through an accompanying RSS (Really Simple Syndication) feed, like those on iTunes, they functioned as podcasts in all other respects. At the term's end, students were surveyed online to ascertain how they made use of the podcasts, and assess their satisfaction with this curriculum delivery method.

\section{Implementation of the Project}

The podcasting project was conducted in an introductory journalism course that examines the structures of 
Table 1

Population Characteristics

J201 Mass Media and Society Fall 2005

University of Oregon School of Journalism \& Communications

Average Age

19.6 yrs.

$100.0 \%$

Standing

Freshman

161

57

Sophomore

25

Junior

Senior

5

Other

Enrollment Status

Full-time

Part-time

\section{Major}

Pre/Journalism $\quad 142$

$57.0 \%$

Pre/Business Administration

English

Economics

Other

$\underline{\text { Sex }}$

Female

mass media industries and the relationships of media and society, in a large lecture format. Table 1 summarizes the class demographics during fall term 2005. Curriculum was prepared and presented by Stavitsky, assisted by three graduate students responsible for proctoring exams, grading, and conferring with students on course-related issues and concerns.

A recurring challenge for Stavitsky was integrating class lectures, which dealt with media-wide issues such as digital convergence and ownership concentration, with assigned readings, which provided industry-by-industry information. In previous years, he used part of one class each week to review assigned chapters. These in-class reviews were accompanied by chapter notes, prepared by Stavitsky to highlight key points, and posted to the course Web site in advance of the appropriate class session. The review 
classes were problematic for several reasons. Stavitsky's process of writing and posting chapter notes was fairly time consuming. In-class reviews occupied time that could be better spent on examining breaking issues in mass media, or exploring specific topics in more detail. Likewise, many students found the in-class reviews time consuming, and repetitive. Taken together, these challenges suggested an opportunity to try a new approach for integrating lectures and text. The personal, portable, and on-demand qualities of podcasting seemed to nicely fit the bill. The school's dean provided a small teaching innovation grant to secure the equipment necessary to pursue the project.

Stavitsky created the initial podcast during the term's second week. Utilizing basic audio production skills from his professional broadcasting background, Stavitsky used a Marantz PMD 660 digital audio recorder to record a nineteen-minute audio summary of six chapters. Working from an outline, Stavitsky employed a conversational style similar to his lectures to relate the basic concepts of each chapter to historic and contemporary issues in mass media and society. The recorded audio file required no additional editing. Subsequently, he uploaded the digital audio recording to the course Web site in .mp3 file format, through the Blackboard course information interface. The smaller .mp3 format, commonly used by students to transfer and store music between their computers and portable audio devices, was chosen to maximize download speed and minimize file storage requirements. ${ }^{22}$ Brief text notes on the chapters accompanied the audio file in the same area of the Web site. Playing on his first name, Stavitsky named the file the "Al Pod."

In class, on the course Web site, and during office visits, Stavitsky and his graduate assistants encouraged students to use the podcasts. Through the Web site, students could listen directly to the Al Pod through any connecting computer, or they could download the file to their personal computer, iPod, or other portable audio device for later playback. Over the succeeding four weeks, new podcasts and notes appeared weekly on the course Blackboard site. Freed from the confines of finite class periods, Stavitsky varied the length of each podcast, from fifteen to twenty-eight minutes, to suit the breadth and depth of the material. Students' anecdotal responses were positive: Borrowing a nickname adopted by MTV's Curry, students at first referred to Stavitsky as "The Podfather." Later, the name became "PDaddy."

As the term moved toward conclusion, Stavitsky collaborated with a doctoral candidate on a survey to assess the students' response to the experiment. The survey consisted of twenty-two multiple-choice questions, plus an opportunity to provide narrative comments, and was posted to the Blackboard site for ten days. Through e-mail and in-class announcements, students were encouraged to complete the survey, and were offered extra credit toward their final course grade as an incentive to participate. The Blackboard interface assured that each student could provide only one set of answers, and all responses were collected anonymously. Students could submit narrative comments, and no particular response could be associated with any individual student. 
Table 2

HOW MANY TIMES DID YOU LISTEN TO EACH PODCAST?

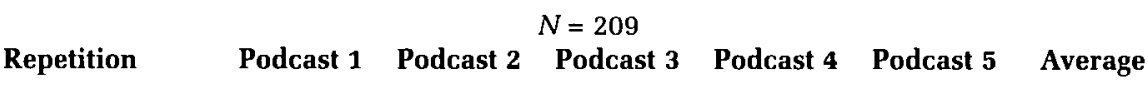

\begin{tabular}{|c|c|c|c|c|c|c|}
\hline $\begin{array}{l}\text { Did not listen } \\
\text { or complete }\end{array}$ & $\begin{array}{r}23 \\
11.0 \%\end{array}$ & $\begin{array}{r}25 \\
12.0 \%\end{array}$ & $\begin{array}{r}25 \\
12.0 \%\end{array}$ & $\begin{array}{r}25 \\
12.0 \%\end{array}$ & $\begin{array}{r}28 \\
13.4 \%\end{array}$ & $\begin{array}{r}25.2 \\
12.1 \%\end{array}$ \\
\hline 1 time & $\begin{array}{r}113 \\
54.1 \%\end{array}$ & $\begin{array}{r}121 \\
57.9 \%\end{array}$ & $\begin{array}{r}126 \\
60.3 \%\end{array}$ & $\begin{array}{r}119 \\
56.9 \%\end{array}$ & $\begin{array}{r}112 \\
53.6 \%\end{array}$ & $\begin{array}{r}118.2 \\
56.5 \%\end{array}$ \\
\hline 2 times & $\begin{array}{r}54 \\
25.8 \%\end{array}$ & $\begin{array}{r}45 \\
21.5 \%\end{array}$ & $\begin{array}{r}42 \\
20.1 \%\end{array}$ & $\begin{array}{r}44 \\
21.0 \%\end{array}$ & $\begin{array}{r}49 \\
23.4 \%\end{array}$ & $\begin{array}{r}46.8 \\
22.3 \%\end{array}$ \\
\hline 3 times or more & $\begin{array}{r}19 \\
9.1 \%\end{array}$ & $\begin{array}{r}17 \\
8.1 \%\end{array}$ & $\begin{array}{r}15 \\
7.2 \%\end{array}$ & $\begin{array}{r}20 \\
9.6 \%\end{array}$ & $\begin{array}{r}20 \\
9.6 \%\end{array}$ & $\begin{array}{r}18.2 \\
8.7 \%\end{array}$ \\
\hline No answer & 0 & $\begin{array}{r}1 \\
0.5 \%\end{array}$ & $\begin{array}{r}1 \\
0.5 \%\end{array}$ & $\begin{array}{r}1 \\
0.5 \%\end{array}$ & 0 & $\begin{array}{l}0.6 \\
.3 \%\end{array}$ \\
\hline
\end{tabular}

At the term's end, the researchers used the Blackboard interface to generate a report of the quantitative and qualitative data. Quantitative data were captured in tables to simplify presentation. Qualitative data were coded into seven categories: reactions to content; reactions to presentation; descriptions of user methods; comments on podcasts as supplementary to the course text; comments on podcasts as replacement for the course text; comments from nonusers; and summative comments.

\section{Survey Results}

Students participated enthusiastically in the Al Pod survey: $83.9 \%$ of the class, or 209 of the 249 students, chose to respond (Table 1). Of these, $\mathbf{8 9 . 0} \%$ listened to the first podcast at least one time, while $34.9 \%$ listened to programs more than once. Over the term, these usage statistics remained fairly constant: On average, $87.6 \%$ listened to the podcasts at least once (Table 2).

Respondents conveyed enthusiastic appreciation for the Al Pods in their narrative comments. While some relied on one or two word generalizations ("great," "good idea," or "they helped"), others took time to express themselves in more detail:

"This is an amazing creation! It totally saved my life, thank you so much for putting this together. It's a great way to further enhance the knowledge of your class material."23

"The Al Pods are the reason I am doing so well in this class. It's nice because it is like we are getting the value of two classes: (1) J201 (on the Al Pod) and (2) the application of the learning in class." 24 
Table 3

HOW MUCH OF EACH PODCAST DID YOU LISTEN TO?

$$
N=209
$$

Completion

Podcast 1 Podcast 2 Podcast

Podcast 4 Podcast 5 Average

All

171
$81.9 \%$

171
$81.9 \%$

167

$79.9 \%$

173

$82.8 \%$

$\begin{array}{rr}168 & 170.0 \\ 80.4 \% & 81.3 \%\end{array}$

More than

14
$6.7 \%$

15

18

12

12

14.2

$8.6 \%$

$5.7 \%$

$5.7 \%$

$6.8 \%$

Less than

3
$1.4 \%$

4
$1.9 \%$

3
$1.4 \%$

o

5
$2.4 \%$

3.0

None

20
$9.5 \%$

19
$9.1 \%$

21
$10.1 \%$

23
$11.0 \%$

24

$11.5 \%$

21.4

$1.4 \%$

No answer

0

0

1
$0.5 \%$

0

0.4

$0.5 \%$

$0.9 \%$

Generally, students thoroughly engaged the $\mathrm{Al}$ Pods. On average, $81.3 \%$ listened to the podcasts in their entirety (Table 3 ). Just $10.2 \%$ chose not to listen, or encountered technical problems that prevented downloading or playback. A small minority of students initiated, but was unable to complete, the podcasts.

The most important survey data captured the way that students used the Al Pods. Not surprisingly, 90.8\% of respondents listened to podcasts during their regular study sessions at home (Table 4). However, 29.7\% indicated that they also listened to the materials while undertaking other unspecified activities. Unfortunately, none of the comments provided more insight into their nature. While the survey did not differentiate those who listened online from those who listened on portable players, $21.9 \%$ listened to the podcasts in nonhome environments, including during exercise, or while in transit by automobile, bus, bicycle, or other transportation.

While the survey did not provide specific insight into these study locations and environments, one comment expressed appreciation for the podcast's ability to fit into the hectic routine of student life: "It was awesome because I was able to listen to it at my own convenience." 25 Other students shared more specific information on how they used the material:

"I would copy and paste all the chapter notes into a Word document, then print it. Then I would lay on my bed and take additional notes on it from what you said, so I could study it later." 26

"It gives the listener the ability to rewind and replay confusing topics." 27 
Table 4

HOW DID YOU USE THE PODCASTS?

$N=209$

\begin{tabular}{lrrr}
\hline Technical Difficulties & $\underline{\text { No }}$ & $\underline{\text { Yes }}$ & No Answer \\
w/Downloads? & 180 & 27 & 2 \\
& $86.2 \%$ & $12.9 \%$ & $0.9 \%$
\end{tabular}

Listening Environments Home/Study

(Multiple Answers

Allowed)

Home/Other

In Transit

Exercising Other

62

$29.7 \%$

19
$9.0 \%$

$5.7 \%$

15

$90.0 \%$

Supplement
120
$57.4 \%$

$\frac{\text { Replacement }}{85}$

No Answer

Textbook

40.7

$1.9 \%$

Do the podcasts

make the

$\frac{\text { Yes }}{41}$

$\frac{\text { Maybe }}{76}$

$19.6 \%$

$36.4 \%$

textbook
unnecessary?

"They were great supplementary materials for studying, especially for someone like me, an international student who can certainly not understand 'all' of the course lectures."28

Though the large majority of students were able to connect, download, and listen to the podcasts without problems, some encountered technical difficulties (Table 4). Of these, some had trouble connecting to the Blackboard server, while more were unable to capture the file for their computer or media player. Some could not diagnose the problem, responding, "it just didn't work." 29 Though all students could listen to the Al Pods by streaming them directly through any computer, some students may have been under the impression that an iPod or other portable device was required to hear the podcasts. One

nonuser's comment demonstrated that some students might need help with understanding and using the technology:

"I appreciate the versatility of the Al Pod, but do not benefit from it as much as others because I do not own a digital media playing device."30

The most problematic area explored by the survey examined the students' perceptions of the relationship between the podcasts and the course text. While a majority used the podcasts as a textbook supplement, more than $40 \%$ chose to use the programs to replace the book (Table 4). More respondents chose to comment on this issue than any other. Those using both the text and the podcasts expressed the view that the Al Pods effectively enhanced the other course materials: 
Table 5

WERE YOU SATISFIED WITH THE PODCASTS?

$N=209$

\begin{tabular}{|c|c|c|c|c|}
\hline $\begin{array}{l}\text { Podcast } \\
\text { Content }\end{array}$ & $\begin{array}{r}\text { About Right } \\
184 \\
88.0 \%\end{array}$ & $\begin{array}{r}\text { Too Much } \\
2 \\
0.9 \%\end{array}$ & $\begin{array}{r}\text { Too Little } \\
18 \\
8.6 \%\end{array}$ & $\begin{array}{r}\text { No Answer } \\
5 \\
2.4 \%\end{array}$ \\
\hline $\begin{array}{l}\text { Podcast } \\
\text { Length }\end{array}$ & $\begin{array}{r}\text { About Right } \\
180 \\
86.1 \%\end{array}$ & $\begin{array}{r}\text { Too Long } \\
19 \\
9.1 \%\end{array}$ & $\begin{array}{r}\text { Too Brief } \\
10 \\
4.9 \%\end{array}$ & $\frac{\text { No Answer }}{0}$ \\
\hline $\begin{array}{l}\text { Podcast } \\
\text { Style }\end{array}$ & $\begin{array}{r}\text { About Right } \\
199 \\
95.2 \%\end{array}$ & $\begin{array}{r}\text { Too Formal } \\
1 \\
0.5 \%\end{array}$ & $\begin{array}{r}\text { Too Informal } \\
3 \\
1.4 \%\end{array}$ & $\begin{array}{r}\text { No Answer } \\
6 \\
2.9 \%\end{array}$ \\
\hline $\begin{array}{l}\text { Overall } \\
\text { Utility }\end{array}$ & $\begin{array}{r}\text { Very Helpful } \\
168 \\
80.4 \%\end{array}$ & $\begin{array}{r}\text { Somewhat Helpful } \\
32 \\
15.3 \%\end{array}$ & $\begin{array}{r}\text { Not Helpful } \\
6 \\
2.9 \%\end{array}$ & $\begin{array}{r}\text { No Answer } \\
3 \\
1.4 \%\end{array}$ \\
\hline $\begin{array}{l}\text { Recommend } \\
\text { Podcasts } \\
\text { to Other }\end{array}$ & $\begin{array}{r}\frac{Y e s}{194} \\
92.8 \%\end{array}$ & $\begin{array}{r}\text { Maybe } \\
13 \\
6.2 \%\end{array}$ & $\frac{\text { No }}{0}$ & $\begin{array}{r}\text { No Answer } \\
2 \\
0.9 \%\end{array}$ \\
\hline
\end{tabular}

J201 Students

"After reading all the chapters I would listen to the pod and follow along with the book just to make sure I didn't miss anything." 31

"I followed along with the chapter notes as Al talked and referred to the text as well. It really helped me catch up and summarized the important parts of the text after reading some lengthy chapters in Vivian."32

"I don't think the pods should replace the readings. My knowledge of the material came from the reading. The $\mathrm{Al}$ Pods were just an emphasis on the major concepts of the material." 33

Other students were equally outspoken that the podcasts rendered the course text unnecessary:

"I felt like the reading notes in combination with the Al Pods really eliminated most of the necessity of reading from the book. When I did read the book, I just skimmed through each section to find the information I knew I was supposed to know."34

"I predominantly used the Al Pod to fill in for course material that I did not read. I can't 
say for sure that I would have done the reading if the Al Pod was not available, but it certainly made the reading unnecessary." 35

"I did not even buy the Vivian textbook because all the information I needed was on the pod."36

Students were split on the textbook's necessity when podcasts covered the same material: Though $34 \%$ responded that Al Pods could not replace the text, almost $20 \%$ felt that the podcasts effectively replaced the book. An even larger percentage was unsure $(36.4 \%)$ or offered no opinion (10\%).

Participants' summative evaluations of the Al Pod experiment were very positive (Table 5). Only two respondents felt the podcasts covered too much material, while $8.6 \%$ wanted more. On the other hand, $9.1 \%$ of respondents found the podcasts too long to sustain their attention.

More than $95 \%$ felt that Stavitsky's programs took the right tone, striking an appropriate balance between information and commentary, presented with an engaging and light touch:

"I especially liked the examples Al would use from his own experience to explain the readings." 37

"There were specific examples that related to the class content, and they were explained, which makes the content easier to understand." 38

"I love the humor! It really breaks the ice and makes studying a little bit more fun!"39

More than $95 \%$ of participants felt that the Al Pods helped them succeed in the class, and they were nearly unanimous in recommending the podcasts to future students. Several respondents expressed sentiments similar to one comment: "I would love to have pods in all my classes." 40

\section{Conclusions}

At the project's conclusion, the researchers were satisfied that the $\mathrm{Al}$ Pod experiment's modest goals had been achieved. Podcasts brought a new and popular technology to the curriculum, engaged student interest, and expanded time available for discussions and lectures in class. Students indicated that the Al Pods were informative, accessible, and added value to their class experiences. The nearly unanimous endorsement for other students demonstrates that the Al Pods enhanced teaching and learning. On the flip side, planning and production of the podcasts added approximately three hours per week to the faculty workload.

The project raises a number of important pedagogical issues. Foremost is whether the podcasts contributed to improved academic performance. This is difficult to discern in a large lecture class of this type, in which most grading is done by graduate-student teaching assistants who change from year to year. This circumstance challenges the ability construct valid pre- and post-podcast comparisons. Nonetheless, this study's outcome allows for speculation that 
increased student engagement, as a consequence of the interest in the podcasts, would lead to more learning and better grades. Further research, carefully designed to account for validity and reliability concerns, would be useful. The project also raises the issue of the impact of podcasting upon classroom interaction, also difficult to measure with precision. However, anecdotal evidence shows the $\mathrm{Al}$ Pods generated considerable classroom discussion, as students asked questions about the content (or teased the instructor about jokes or self-deprecating stories contained therein).

The project raised another significant concern with regard to the podcasts' impact on use of the course textbook. The survey indicated-and anecdotal comments underscored-that some students decided that the chapter summaries and synthesis included in the podcasts obviated the need for assigned textbook readings. Though the instructor viewed the podcasts as a way to add value to the readings, some students chose to substitute the $\mathrm{Al}$ Pods for the textbook. This is a thorny issue, and the instructor is faced with divergent approaches: rethinking how to make the podcasts complement the readings without providing enough detail to make the text seem unnecessary, or conceptualizing the podcasts as a substitute for the text-as, in effect, an aural packet of readings, augmented perhaps by online sources. The latter approach would likely make the podcasts considerably longer, require considerably more faculty preparation time, and could easily raise copyright issues. At the same time, this approach would reduce student cost and encourage innovative thinking about the delivery of course content.
Given the time commitment required for this application, faculty who are considering podcasting would be wise to reflect on institutional reward structures. Would administrators consider podcasting as a form of curricular development for purposes of tenure and promotion, or for merit pay increases?

With the potential benefits noted in this article, it seems inevitable that podcasting will be recognized as a valuable teaching tool. However, in this formative period, early adopters may have to do some missionary work to ensure that podcasting is incorporated into existing college and university reward structures.

Given this study's scope, its findings are too limited to generalize to other circumstances. As a pilot project, the Al Pod raises a number of intriguing research questions that need to be addressed in future studies:

What are the relationships of demographics to podcast usage? How do differences of gender, class standing, and major, among other characteristics, influence user preferences, habits, and satisfaction?

What percentage of students listened to podcasts directly through their computers, versus transferring them to portable devices?

What conditions constrained students from listening to podcasts they had downloaded?

For hearing and visually impaired students, what issues related to audio and video podcasting might be raised under the Americans with Disabilities Act?

Future investigations, following the same basic research design, would provide a more complete understanding of the advantages and shortcom- 
ings of educational podcasting. Such studies could incorporate one-on-one follow-up interviews or techniques to ascertain in-depth how students used podcasts, and how the podcasts helped individual students more specifically. Generally, the broader issue of the role of text-based materials in higher education, within the context of multiple curricula delivery technologies, deserves further investigation. In particular, future research may consider the efficacy of aural versus visual learning materials with relationship to individual learning styles and study practices.

A recent University of Missouri white paper concludes "the ability to time-shift content versus traditional broadcast distribution models [including class lectures] expands student teaching and learning opportunities significantly."41 The rapid penetration of portable audio devices represents an opportunity for educators to engage students directly beyond the classroom, in a manner consistent with the lifestyles and behaviors of today's students. While podcasting may challenge some of the time-honored traditions of higher education, the Al Pod experiment shows that such challenges open the door to a host of opportunities to enhance our students' learning experience.

\section{Endnotes}

1. Bridge Ratings, The State of Podcasting, 2005, http://www.bridgeratings.com/Images/The $\% 20$ Future $\% 20$ of $\% 20$ Podcasting $\% 20$ Slides_files/ frame.htm (November 27, 2005).
2. National Retail Federation, "2005 Back to College Spending by Age," August 16, 2005, http://www.nrf. com/content/default.asp?folder=press/ holiday\&file=BTCage0805.htm (January 24,2006 ).

3. Apple iTunes Music Store, "Podcasts: Education: Higher Education," January 24, 2006, http://www. apple.com/itunes/ (24 January 2006).

4. Drexel University, "Drexel's Podcast Series," 2005, http://www. drexel.com/podcast/ (January 24, 2006).

5. Stanford University, "Stanford on iTunes," 2005, http://itunes.stan ford.edu/index.html (January 24, 2006).

6. Brock Read, "Lectures on the Go," Chronicle of Higher Education (October 28, 2005), sec. A, pp. 39-42.

7. John Pavlik, in Everette E. Dennis, Phillip Meyer, S. Shyam Sundar, Larry Pryor, Everett M. Rogers, Helen L. Chen, and John Pavlik, "Learning Reconsidered: Education in the Digital Age," Journalism \& Mass Communication Educator (winter 2003): 314-15.

8. Raul Reis, Alan G. Stavitsky, Tim Gleason, and William Ryan, "Journalism at a Distance: The Oregon Experiment," Journalism \& Mass Communication Educator (winter 2000): 21.

9. Reis et al., "Journalism at a Distance: The Oregon Experiment," 2122.

10. Kenneth R. Blake, "Using the World Wide Web to Teach News Writing Online," Journalism \& Mass Communication Educator (spring 2000): 8-11.

11. Bruce Henderson, "Improving Student Writing Using a Web-based Targeted Approach to Grammar System (TAGS)," Journalism \& Mass Communication Educator (autumn 2002): 
241.

12. IPodder.org, "Podcasting History," December 15, 2004, http:// www.ipodder.org/history (November 30, 2005).

13. Ken Freedman, telephone interview by Michael Huntsberger, minidisc recording (October 19, 2005), University of Oregon, Eugene.

14. Jeffrey R. Young, "New Princeton Web Service Offers Recordings of Public Policy Lectures," Chronicle of Higher Education (August 12, 2005), sec. A, p. 34.

15. Read, "Lectures on the Go."

16. William Ferguson, "Now, Lectures Anytime, Anywhere," New York Times (November 6, 2005), sec. 4A, p. 7, col. 1.

17. Vin Capone, "Podcasting," presentation at the University of Oregon (January 10, 2006).

18. Jeffrey $R$ Young, "Stanford U. Makes Podcasts of Lectures Available through Apple's iTunes," Chronicle of Higher Education (November 4, 2005), sec. A, p. 44.

19. Read, "Lectures on the Go."

20. Read, "Lectures on the Go."

21. Read, "Lectures on the Go."

22. A wide variety of print and online sources are available for those interested in more specific information on podcast production, including Todd Cochrane, Podcasting: The Do-ItYourself Guide (Indianapolis, IN: Wiley Publishing, 2005); and Kirk McElhearn, Beginner's Guide to Podcast Creation, available online at http:// www.ilounge.com/index.php/articles/ comments/beginners-guide-to-podcastcreation/.

23. Alan G. Stavitsky, "Assessment statistics the Al Pod survey - J201 Fall 05" (Web page printout, University of Oregon, 2005), 6.
24. Stavitsky, "Assessment statistics the Al Pod survey - J201 Fall 05," 7.

25. Stavitsky, "Assessment statistics the Al Pod survey - J201 Fall 05."

26. Stavitsky, "Assessment statistics the Al Pod survey - J201 Fall 05," 8.

27. Stavitsky, "Assessment statistics the Al Pod survey - J201 Fall 05."

28. Stavitsky, "Assessment statistics the Al Pod survey - J201 Fall 05," 6.

29. Stavitsky, "Assessment statistics the Al Pod survey - J201 Fall 05," 1.

30. Stavitsky, "Assessment statistics the Al Pod survey - J201 Fall 05," 11.

31. Stavitsky, "Assessment statistics the Al Pod survey - J201 Fall 05," 9.

32. Stavitsky, "Assessment statistics the Al Pod survey - J201 Fall 05," 6.

33. Stavitsky, "Assessment statistics the Al Pod survey - J201 Fall 05."

34. Stavitsky, "Assessment statistics the Al Pod survey - J201 Fall 05," 8

35. Stavitsky, "Assessment statistics the Al Pod survey - J201 Fall 05," 6.

36. Stavitsky, "Assessment statistics the Al Pod survey - J201 Fall 05," 10.

37. Stavitsky, "Assessment statistics the Al Pod survey - J201 Fall 05," 11.

38. Stavitsky, "Assessment statistics the Al Pod survey - J201 Fall 05," 7.

39. Stavitsky, "Assessment statistics the Al Pod survey - J201 Fall 05," 6.

40. Stavitsky, "Assessment statis- 
tics the Al Pod survey - J201 Fall 05," 11.

41. Peter Meng, "Podcasting and vodcasting: A white paper," March 10
2005, http://edmarketing.apple.com/ adcinstitute/wp-content/Missouri_ Podcasting_White_Paper.pdf (January 26,2005 ). 